\title{
Effect of Time and Extent of Harvesting Basin Wildrye ${ }^{1}$
}

\section{JAMES L. KRALL, JAMES R. STROH, CLEE S. COOPER, AND STEPHEN R. CHAPMAN}

Superintendent, Huntley Branch Experiment Station, Huntley; Manager, Bridger Plant Material Center, Soil Conservation Service, Bridger; Agronomist Crops Research Division, Argicultural Reseach Service, U. S. Department of Agriculture, Bozeman; and Associate Professor, Plant and Soil Science Department, Montana State University, Bozeman, Montana.

\section{Highlight}

Single clipping treatments of basin wildrye during the period of growth initiation to full bloom followed by removal of all growth to a $5 \mathrm{~cm}$ stubble at the end of the growing season reduced yields in the year of clipping and the year following. Growth reduction was greatest when plants were clipped at the boot stage. Removal of $1 / 4,1 / 2,3 / 4$ or all of the herbage at any one of three dates in the spring of one year reduced yield the following year. Growth decreased as the level of herbage removal increased and with years of treatment or delay in harvest time when $3 / 4$ or all of the herbage was cut. Growth reduction was greatest when herbage was cut at the boot stage which coincided with the period of rapid elevation of growing points above the soil surface and with a decrease in total available carbohydrates (TAC). Grazing of basin wildrye in early spring, based on data presented, would probably be quite detrimental just as cutting was.

Basin wildrye (Elymus cinerus Scribn. and Merr.) has often attracted the range manager because of its early growth and good production. The species is often confused with giant wildrye (Elymus condensatus Presl.). The two spe-

${ }^{1}$ Joint contribution from the Montand Agricultural Experiment Station, Bozeman, Montana, the Crops Research Division, Agricultural Research Service, U. S. Department of Argiculture and the Plant Materials Center, Soil Conservation Service, Bridger, Montana. Published with the approval of the Director of the Montana Agricultural Experiment Station as Journal Series No. 218. Received October 28, 1970; accepted for publication February 24, 1971. cies differ mainly in pubescence of lemmas, compoundness of spike, width of leaf blades and area of adaptation (Hitchcock, 1950). Giant wildrye is found on sandy areas mostly near the coast from Alameda county to San Diego county California; whereas basin wildrye is found on river banks, in ravines, on moist or dry slopes and on the plains from Minnesota to British Columbia, and south to Colorado and California.

Most descriptions of basin wildrye have been given under the heading of giant rather than basin. In all future reference in this paper basin wildrye will be used whether the literature cited refers to giant or basin.

Perhaps the best description of basin wildrye is given in the Range Plant Handbook (Anonymous, 1937). Excerpts from this description are as follows: "It is a coarse, robust plant with stems up to 12 feet high and growing in large bunches, often several feet in diameter, from short, thick, knotted, perennial rootstocks. This bunchgrass usually grows in moist or wet saline situations in bottomlands, along stream and ditch banks, and in gullies and canyons. It is also found in moderately dry, rich soils, not uncommonly associated with wheatgrass and sagebrush. Basin wildrye is grazed to some extent while young, but soon becomes coarse and tough and is not utilized as summer forage if more palatable feed is available. However, the plants produce an enormous amount of forage and, where allowed to stand, provide a considerable amount of winter feed for cattle and horses. Formerly this species was very important as a winter forage plant in parts of Nevada, but overgrazing, especially during the spring months when growth was starting, has greatly reduced or eliminated it."

"In Oregon and Washington, where basin wildrye occurs in considerable abundance, this species is extensively cut for hay and, if mowed early, provides fair roughage. It is moderately palatable to cattle and horses in California and the Northwest, except during the fall when it becomes very hard and dry. After winter rains begin it softens and is again grazed. Basin wildrye rates as an inferior forage 
species, insofar as palatibility and nutritive quality. The following chcmical analysis compares the composition of basin wildrye with the average of 67 common western range grasses (Knight et al., 1911):"

$\begin{array}{cc}\begin{array}{c}\text { Basin } \\ \text { wildrye }\end{array} & \begin{array}{c}\text { Average com } \\ \text { position, 67 } \\ (\%)\end{array} \\ \text { grasses (\%) } \\ 9.81 & 7.48 \\ 1.13 & 2.05 \\ 40.82 & 35.92 \\ 9.01 & 8.02 \\ & \\ 39.15 & 46.53\end{array}$

Ash

Ether extract

Crude fiber

Crude protein

Nitrogen-free extract

39.15

46.53

The seasonal growth pattern of basin wildrye differs from those of other dryland cool-season grasses. The phenological events of this species occur over an extended period of time. Winter dormancy is broken in early March at Bridger, Montana, with the first leaves emerging between March 10 and March 20. Growth is retarded at this time by continued cool temperatures. Basin wildrye starts spring growth five days earlier than bluebunch wheatgrass (Agropyron spicatum (Pursh.) Scribn. and Smith) but reaches the heading stage 13 days later. It blooms 13 days later and matures seed 16 days later. ${ }^{2}$ The very long vegetative stage delays other phenological stages and causes this early spring growing species to be classed as a late maturing plant. The extended vegetative stage and prolific vegetative production would seem to make basin wildrye an ideal spring grazing plant.

The major problem in maintaining basin wildrye as pasture seems to be its lack of resistance to spring grazing. Because of the paucity of information concerning this species we studied: (1) the effect of clipping once during the growing season upon total season yield (first cut plus regrowth) and upon subsequent yield; (2) the effect of time and amount of herbage removal on growth; and (3) the pattern of growing point elongation and seasonal carbohydrate trends.

\footnotetext{
${ }^{2}$ Unpublished data, Bridger Plant Materials Center, Bridger, Montana.
}

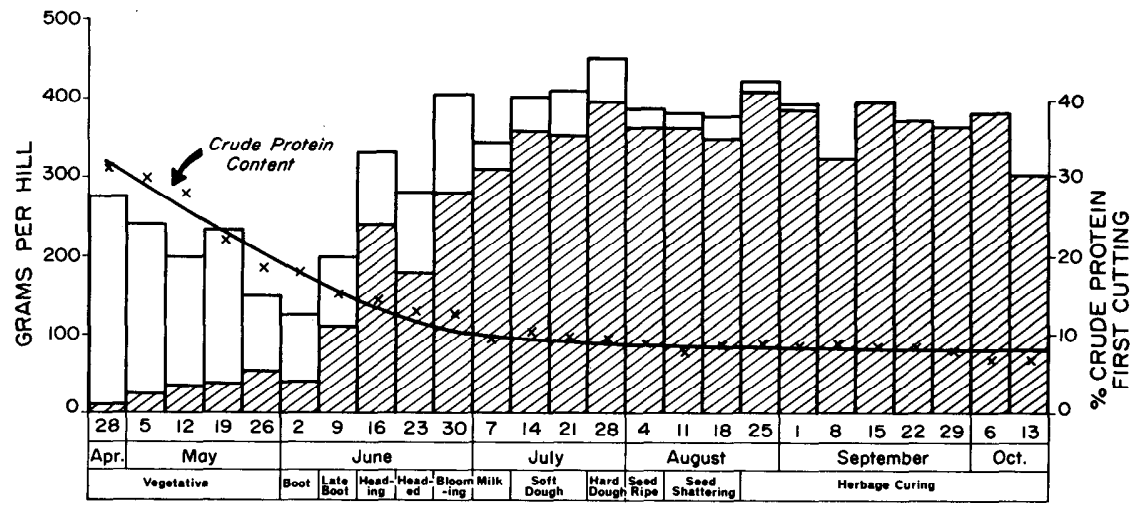

FIG. 1. Yield at time of clipping (hatched bars), regrowth yield (plain bars) and crude protein content of basin wildrye in 1966 at Bridger, Montana.

\section{Seasonal Growth Patterns, Regrowth and Protein Content}

\section{Procedure}

Basin wildrye was planted in 150 hills spaced on 3-foot centers at Bridger, Montana, in April, 1965. Ten seeds were planted in each hill. In 1966 one hundred vigorous hills were selected for study and divided into four replications of 25 hills each. Each hill within a replication was assigned one of 25 clipping dates at which time it was clipped to a 5 -cm stubble height. The data from these treatments provided a seasonal growth curve over a 25-week period. The herbage harvested on these dates was analyzed for crude protein content.
All plants were again clipped to a $5-\mathrm{cm}$ stubble height to measure regrowth on November 2, 1966.

On June 19, 1967, plants were harvested at the boot stage. Yields obtained were used to evaluate the effect of clipping treatments in the previous year. During the study the experimental area was not fertilized, but was adequately supplied with water and was kept weed free.

\section{Results and Discussion}

The growth curve of basin wildrye, as shown by weekly interval harvests, was typical of that expected for a grass (Fig. 1). Cutting prior to bloom reduced the total seasonal yield (first cutting plus regrowth). Yield reduction was most

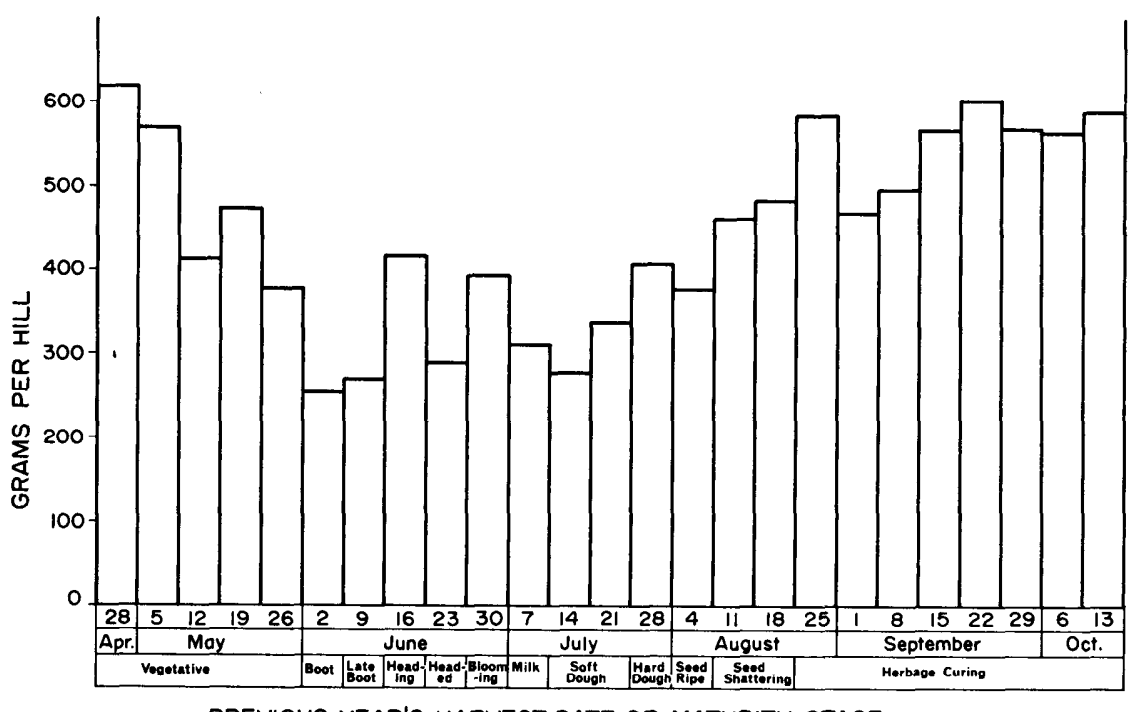

PREVIOUS YEAR'S HARVEST DATE OR MATURITY STAGE

FIG. 2. The effect of a single clipping at different dates in 1966 (weekly intervals) on the yield of basin wildrye in 1967 at Bridger, Montana. 


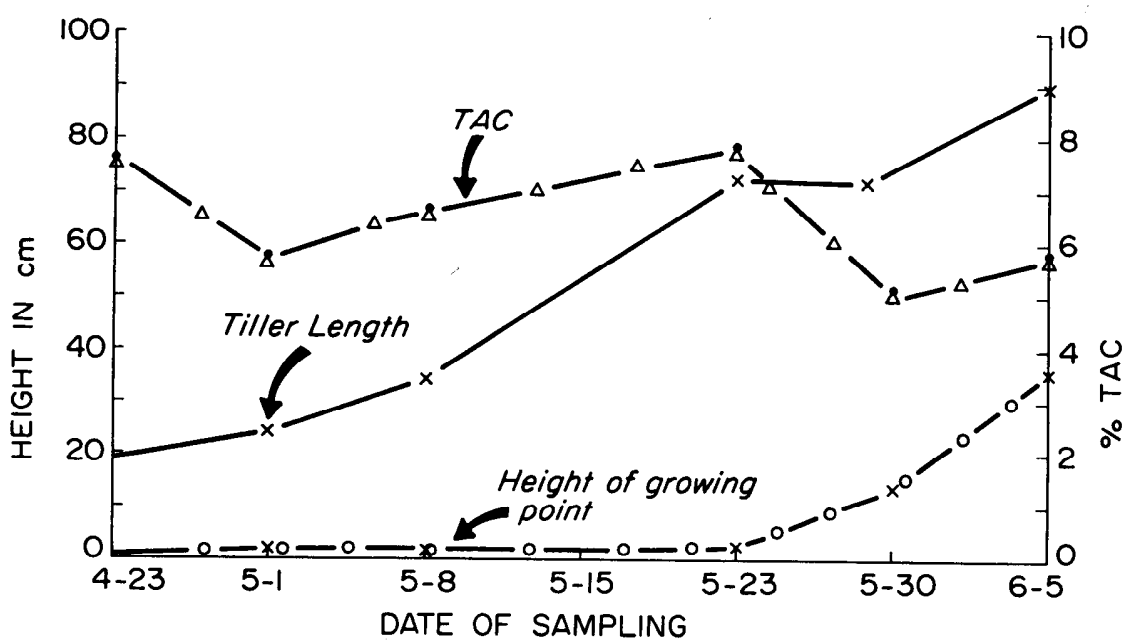

FIG. 3. Tiller length, height of growing point and total available carbohydrates (TAC) in crowns of basin wildrye during the early spring growing season at Bozeman, Montana.

of the strain Wy 107 from the onset of growth until heading. Four or more plants were sampled weekly from April 23 to June 5. Five random tillers were selected from each plant for measurements at each sampling date. The height of the growing point and length of the tiller were measured from the point of tiller attachment to the root. At each sampling date basal stem tissue was separated from each plant for analysis of TAC by the enzyme hydrolysis technique (Smith, 1969).

\section{Results and Discussion}

Tillers increased in length in the manner expected in a normal growth pattern (Fig. 3). Growing points did not protrudc above the soil surface until early boot stage on May 23. From this date until June 5 heads in the boot elongated from 1.2 to $13.2 \mathrm{~cm}$. TAC was less than $8 \%$ at growth initiation. It declined to less than $5 \%$ with the initiation of new growth, rose to nearly $8 \%$ at early boot and declined again during head development. The seasonal pattern of TAC was similar to that observed for bromegrass during similar stages of development (Okajima and Smith, 1964). The values reported are slightly lower than those reported for bromegrass (Okajima and Smith, 1964), and are much lower than those reported for crested wheat- grass (Hyder and Sneva, 1959) during similar stages of development. Baker and Garwood (1961), however, report levels of 4 to $6 \%$ TAC in orchardgrass throughout April and May. The level of TAC. in one species as compared to that of another may have little significance in determining susceptibilty to grazing intensity. Specics secm to vary a great deal in levels of TAC stored and the seasonal pattern within a particular species may be markedly affected by climatic conditions and thus vary from location to location (Blaser et al., 1966).

Our data (Fig. 3) may explain detrimental effects of cutting basin wildrye at the early boot stage (Figs. 1 and 2). At the time of head clongation, carbohydrates decreased, and the growing point was elevated to where it could be removed by grazing. Branson (1953) reported that the height to which growing points are elevated, and the ratio of fertile to vegetative stems are factors critical to the persistence of a species under grazing pressure. We estimated that $90 \%$ or more of the stems of these basin wildrye plants were fertile, which is a high proportion. Thus, if we utilize basin wildrye at the boot stage, we are not only grazing at a time of low TAC but are also removing the growing point which interferes with regeneration of photosynthetic tissue.

\section{Discussion}

One harvest of all of the herbage of basin wildrye during the period from the onset of spring growth through full bloom will decrease total season yields. Furthermore, harvest during this period results in yield reduction the following year. The most critical period of harvest was during the boot stage. At this time, growing points are elongating rapidly above the soil surface. This period of growing point elongation is associated with head formation and appears to be accompanied by a drop in total available carbohydrate in crowns.

From our time of clipping and herbage removal studies it appears that management to permit grazing this species in early spring is possible on a limited basis. Such management, however, would require that no more than $50 \%$ of the herbage be utilized and that it be grazed prior to the boot stage. It is difficult, however, to control grazing to remove only $1 / 2$ of the herbage. Grazing systems which permit periodic rest from grazing during early growth and booting stages might be effective in maintaining the species and should be evaluated. Because of its earliness and yield potential, effective spring utilization of basin wildrye could lengthen the grazing season by several weeks. The difficulty of managing this sensitive species, however, might outweigh the advantages which could accrue.

\section{Literature Cited}

Anonymous. 1937. Range Plant Handbook. Forest Service, U. S. Dep. Agr., Washington, D. C.

BaKer, J. K., AND E. A. Garwood. 1961. Studies of root development in plants $\mathrm{V}$ : Seasonal changes in fructosans and soluble-sugar contents of cocksfoot herbage, stubble and roots under two cutting treatments. J. of British Grassland Soc. 16:263-267.

Blaser, R. E., R. H. Brown, and H. T. BRYANT. 1966. The relationship between carbohydrate accumulation and growth of grasses under different microclimates. Int. Grassland Congr. Proc. 10:147-150.

Branson, Farrel A. 1953. Two new 
factors affecting resistance of grasses to grazing. J. Range Manage. 6:165171.

Hitchсоск, A. S. 1950. Manual of the Grasses of the United States. 2nd Edition. U. S. Dep. of Agr. Misc. Publ. No. 200. 1051 p.

Hyder, D. N., And F. A. Sneva. 1959. Growth and carbohydrate trends in Crested Wheatgrass. J. Range Manage. 12:271-276.
Knight, H. G., F. E. Hepner, and A. Nelson. 1911. Wyoming Forage Plants and their chemical composition, Studies No. 4. Wyo. Agr. Exp. Sta. Bull. 87. 152 p.

Okajima, Hideo, and Dai.f Smith. 1964. Available carbohydrate fractions in the stem bases and seed of timothy, smooth bromcgrass, and scveral northern grasses. Agron. J. 4: 317-320.
Smith, Dale. 1969. Removing and analyzing total nonstructural carbohydrates from plant tissue. Research Report 41. College of Agr. and Life Sci. Univ. of Wisconsin.

Stroh, James R., and Alvin G. Law. 1967. Effects of defoliation on the longevity of stand, dry matter yields and forage quality of Tall Wheatgrass (Agropyron elongatum Host Beauv.). Agron. J. 59: 432-435. 